\title{
Environmental and Anthropogenic Factors in the Development of Geodynamical Processes in Racha
}

\author{
Elene Salukvadze ${ }^{1 *}$
}

\begin{abstract}
The work describes and assesses the main physical-geographical and anthropogenic factors in the development and characteristic activation of geodynamic processes in Racha. The morphometric (hypsometric, mountain sloping, slope aspect) values are calculated and described. The paper also touches on the quantitative data that give the characteristics of the relief, climate, soil and vegetation cover and influence the development and activation of geodynamical processes. For studying the tasks mentioned above, we selected the mountainous region - Racha (municipalities of Ambrolauri and Oni). For the studies, together with literary material and different sources, we used cartographic material, the landscape maps $(1970,1983)$ and the topographic map (scale; 1:100 000) of Georgia and Transcaucasia and the observation materials of the field expedition made in 2019-2021 in Racha. Racha is a mountainous region characterized by complex relief and geological structure. Here, nearly all kinds of hazardous geodynamical processes such as landslides, mudflows, erosion, rock flows, avalanches, karst and suffosive phenomena are observed, though the most frequent are landslides, mudflows erosive processes and washing-off of river banks. The activation of the geodynamical process and the hazard of large-scale development of gravitational phenomena are extremely increased because the whole region territory is prone to earthquakes of intensity VII-IX. Among the most critical factors in geodynamical processes are geological, geomorphological, climatic, and anthropogenic factors. The data on the triggering factors of the main geodynamical processes - erosion, landslide, mudflow, etc. in Racha are given in the tables and diagrams of the paper.
\end{abstract}

Keywords: Geodynamical processes, erosion, landslide, mudflow, Racha

\section{Introduction}

Racha is located in the north-eastern part of West Georgia, on the southern slopes of the Central Caucasus and is bordered by the main watershed of the Caucasus, the ridges of Lechkhumi and Racha.

The territory of Racha is one of the mountainous regions of Georgia, where erosive and other hazardous geodynamical processes (landslides, mudflows, avalanches, rock flows, etc.) take place in different degrees (fig.1).

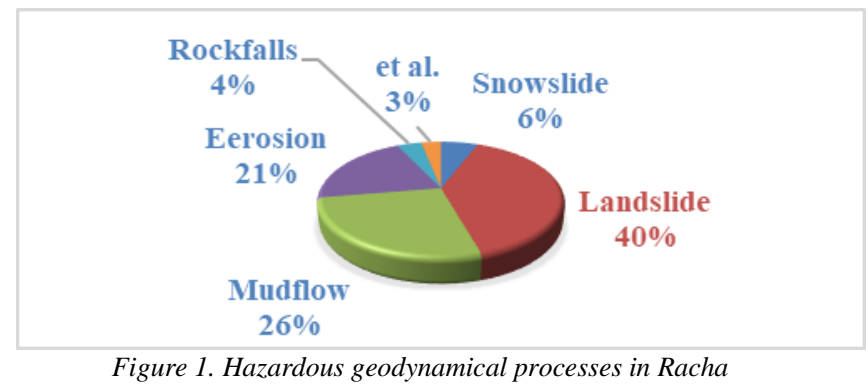

The economic damage caused by them is enormous and dangerous for the environment. Among all the well-known geodynamical processes in Racha - erosion (with different types), landslides and mudflows are the most hazardous phenomena.

Among the factors, which have a unique role in generating geodynamical hazardous processes, the main ones are the lithological structure, history of the relief development and age, morphologic characteristics of the mountain region, hydrologic conditions, behaviour of soil and vegetation cover and also anthropogenic factors.

\section{Study Area}

Region Racha, is located in the northeastern part of West Georgia on the Central Caucasus (Fig.2), on the south slopes of the main ridge of the Caucasus includes two administrative centers: municipalities

\footnotetext{
${ }^{1}$ Vakhushti Bagrationi Institute of Geography, Ivane Javakhishvili Tbilisi State University. Tbilisi, Georgia

* Corresponding author: elene.salukvadze@tsu.ge
} 
of Ambrolauri and Oni. Characteristically the complex, segmented relief and severe climate conditions, high-hypsometric location, extreme land shortage, great inclination of slopes. region distinguished for its diversity in nature.

$22 \%$ of the territory is occupied with lowlands, $78 \%$ is covered with mountains and foothills with high-mountainous, middle-mountainous and low-mountainous type reliefs.

The greater part of Racha is occupied by mountainous forests and alpine valleys. The lowlands consist of a succession of small uplands and a pit and is covered by shrubs, meadows and mostly by anthropogenic landscapes [1].

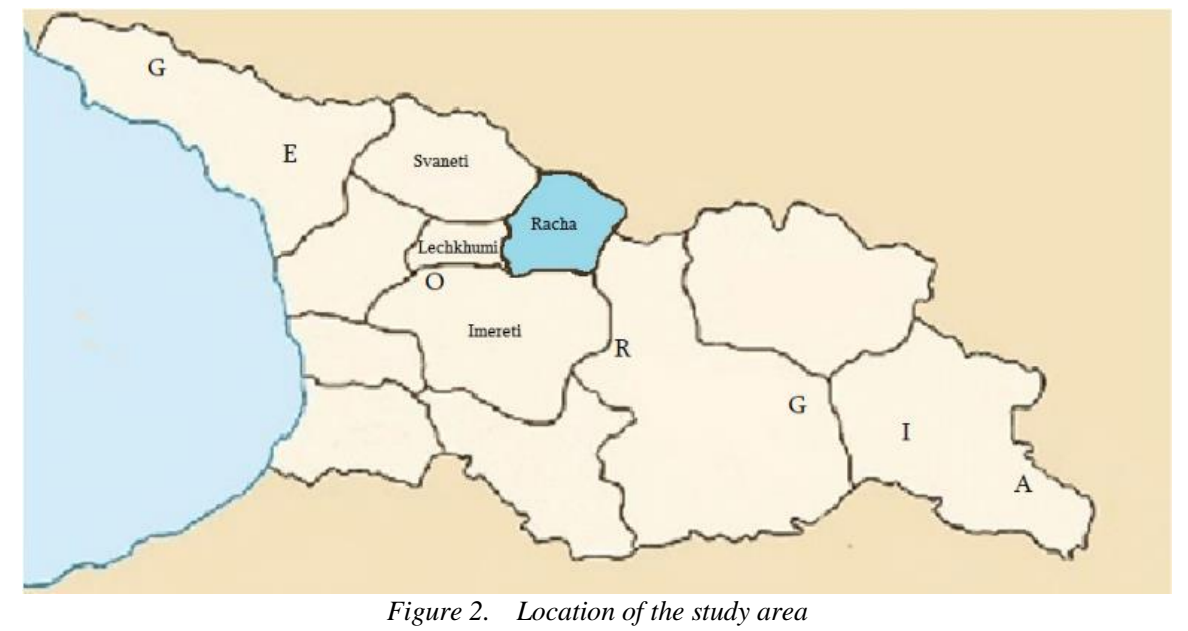

\section{Methods and Materials}

The research is based on a complex physical-geographic, field, cartographic, semi-stationary observation methods. The research was based on the existing published literary and foundation material about Racha region. Namely, Landscape map Georgia [2] and Transcaucasus Medium-Sized Landscape Map [3], also Topographic Maps Racha region (scale: 1: 50 000, 1: 100 000) [4] and statistic data. The important component was the field expedition research conducted in 2019- 2021.

\section{Results and Discussion}

Complex fractured relief characterizes the territory of Racha, clearly expressed vertical zonality and diversity of soil-climatic conditions. Its complexity of natural factors that are the reason for the intensity of erosive processes distinguishes the region of Racha. Rocks, particularly prone to erosion, are widely distributed here.

Regarding Geomorphology, the territory of Racha includes the following vast orographic elements: the main ridge of the Caucasus, the Shoda-Kedela Ridge, the gorge of the river Rioni, The Racha Depression (the Racha Syncline), and the northern slopes of the Racha Ridge. In the relief's development, together with tectonic and erosive-accumulative, karst, gravity and other processes, the modern and old glaciations have an active role. Its complex geological structure distinguishes the relief of Racha. The top of the Caucasus Ridge has a horst-anticline structure. Its crystalline core reaches 4000-4500 $\mathrm{m}$ above sea level and is outcropped because of erosive processes; it is composed of prePalaeozoic and Palaeozoic granite, gneiss and schist [5].

Several structural-tectonic zones are distinguished in the system of the folded southern slopes of the Caucasus. The relief of the mountainous Racha Depression is built of lower Jurassic noncarbonated flysch sediments-sandstone, slate, etc. The Shoda-Kedela Ridge is composed of upper Jurassic and lower Cretaceous carbonate flysch sediments (limestone, marl, sandstone, and slate). The eastern part of Racha (the depressions of upper Racha and Oni-Sori) is composed of Lias slate, sandstone and Bajocian porphyry.

The Racha-Lechkhumi Syncline, which in relief coincides with depression with the same name, is built of Oligocene and Miocene sediments-clay, sandstone, conglomerate and limestone [6].

In the development of geodynamic processes, the orographic properties of the territory, hypsometric disposition and exposition, sloping of the relief surface, fragmentation degree, etc., are of great significance (Table 1.). 
Table 1. Altitudinal subdivision of Racha

\begin{tabular}{|c|c|c|}
\hline $\begin{array}{c}\text { Elevation } \\
(\mathrm{m})\end{array}$ & Area $\mathbf{~ k m}^{\mathbf{2}} \mathbf{K}$ & \% of the total area of Racha \\
\hline $300-500$ & 13.7 & 0.55 \\
\hline $500-1000$ & 265.0 & 10.7 \\
\hline $1000-1500$ & 730.4 & 29.4 \\
\hline $1500-2000$ & 834.8 & 33.8 \\
\hline $2000-2500$ & 291.8 & 11.8 \\
\hline $2500-3000$ & 181.6 & 7.5 \\
\hline $3000-3500$ & 105.3 & 4.2 \\
\hline $3500>$ & 45.4 & 1.8 \\
\hline Total & $\mathbf{2 4 6 8}$ & $\mathbf{1 0 0}$ \\
\hline
\end{tabular}

The table shows that most area of Racha are occupied with middle-mountainous relief (33.8\%). The hypsometric zones express the considerable fragmentation degree of the surface of the territory of Racha.

Length of the mountain slope, exposition, and form immediately influenced the washing-off process in the soil.

Relief sloping has a significant role in the speed of water flow and erosive energy. We distinguished gradations of surface deviation values on the study territory as described below (Table 2.).

Table 2. Sloping surface of relief of Racha

\begin{tabular}{|c|c|c|}
\hline Slope & ${\text { Area } \mathbf{~ k m}^{2}}^{\mathbf{2}}$ & \% of the total area of Racha \\
\hline $0-5^{\circ}$ & 172.4 & 6.9 \\
\hline $5-10^{\circ}$ & 295.8 & 11.9 \\
\hline $10-15^{\circ}$ & 355.2 & 14.3 \\
\hline $15-20^{\circ}$ & 377.3 & 15.2 \\
\hline $20-25^{\circ}$ & 375.2 & 15.2 \\
\hline $25-30^{\circ}$ & 359.5 & 14.5 \\
\hline $30-35^{\circ}$ & 291.7 & 11.8 \\
\hline $35-45^{\circ}$ & 183.9 & 7.4 \\
\hline $45^{\circ}>$ & 57.2 & 2.8 \\
\hline Total & $\mathbf{2 4 6 8}$ & $\mathbf{1 0 0}$ \\
\hline
\end{tabular}

As shown in the table, the moderately sloped relief $(15-20 \%, 20-25 \%)$ occupies most of the area, totally of $30.4 \%$, extremely sloped relief (25-30\%) covers $14.5 \%$, steep slopes (30-35\%) make $19.2 \%$ and sheer cliffs cover $2.8 \%$ of the territory.

The arable lands that are on slopes with over $35^{\circ}$ declination are prone to liquid impact erosion and require soil-conserving activities. In Racha, the modern erosive processes are widely distributed in flysch, terrigenous and volcanic sediments. In the existing relief conditions, the erosive processes differ from one another in activities and have different strengths at different places. Erosive processes have destroyed or partially made gullies on hundreds of hectares of arable lands, ruined roads and bridges, homes, etc.

In Racha, there are two kinds of erosion: vertical and lateral. Surface washing-off (with soil erosion) is widely distributed here. In most of the territory, vertical erosion is observed. It is observed in the areas of nearly all tributaries of the rivers Rioni and Jejori because of the great thickness of the deluvium cover, an abundance of atmospheric precipitations and flow of underground waters at little depths [7]. Vertical erosion is extreme during summer rains and snow melting periods. At the same time, vertical erosion becomes more severe because of ploughing activities on slopes, which are highly slanted. It is hazardous regarding the development of liquid impact erosion. Lateral erosion is observed almost everywhere, and hundreds of hectares of fertile soil are degraded for this reason. Terraces are intensively washed down in town Ambrolauri, villages of Sori, Shardometi, Chrebalo, etc.

On different exposition slopes, the processes of snow melting warming of soil and vegetation differ, namely, snow melts earlier on the south exposition slopes of the Racha ridges than on the north exposition slopes. It, in its turn, develops different regimes in the hydrologic network. Additionally, different exposition slopes receive a different quantity of atmospheric precipitation that, together with lithological composition, is in close relation with the development of landslides, avalanches and erosive processes (fig.3). 


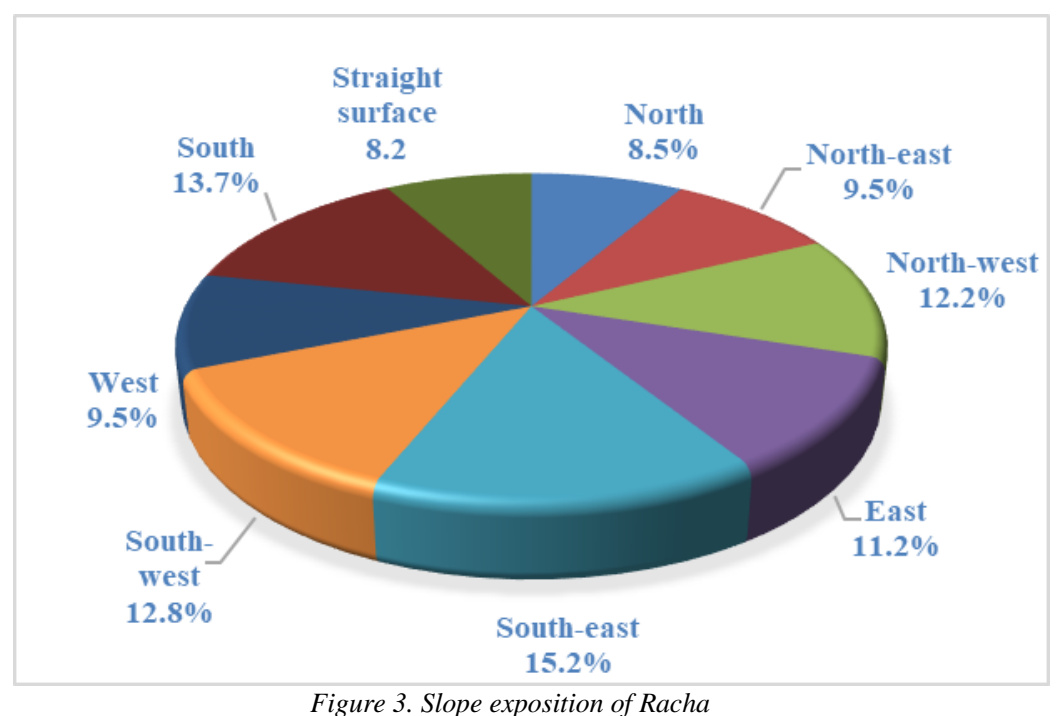

The diagram of the slope exposition distribution on the territory of Racha shows that mainly southern, south-eastern and south-western slopes dominate the study territory. The slope expositions influence the intensity of shadowing and lighting and the soil temperature of a slope. The north exposition slopes receive less direct solar radiation during a whole year than the horizontal exposition surfaces, while the south exposition slopes have more of it. It is the same in the cases of other climatic elements.

Besides relief and lithological structure, the climate factor is also significant. Namely, the number of precipitations and temperature are the most important.

Racha is located in the humid subtropical zone of West Georgia. Considerable distance from the sea, morphological and morphometric properties of the relief define the climate here. The climate in Racha is transient from humid subtropical to continental.

Erosion, potential hazards of landslides and mudflows are influenced by precipitation quantity. On the one hand, precipitation distribution during a whole year is more significant for the generation of erosion (Table 3).

Table 3. Distribution during a whole year in Racha

\begin{tabular}{|l|l|l|l|l|l|l|l|l|l|l|l|l|l|l|}
\hline \multirow{2}{*}{ Object } & \multicolumn{10}{|c|}{ Month (mm) } \\
\cline { 2 - 17 } & I & II & III & IV & V & VI & VII & VIII & IX & X & XI & XII & Per year & $\begin{array}{l}\text { Daily } \\
\text { Max (mm) }\end{array}$ \\
& & & & & & & & & & & & & & \\
& & & & & & & & & & & & & & \\
\hline Ambrolauri & 79 & 86 & 86 & 86 & 105 & 99 & 81 & 80 & 87 & 99 & 94 & 93 & 1075 & 92 \\
\hline Oni & 77 & 81 & 81 & 84 & 103 & 98 & 80 & 79 & 86 & 98 & 92 & 89 & 1050 & 98 \\
\hline Utsera & 110 & 115 & 115 & 120 & 149 & 140 & 113 & 112 & 122 & 141 & 132 & 126 & 1495 & 130 \\
\hline Shovi & 95 & 102 & 103 & 101 & 122 & 114 & 91 & 92 & 102 & 118 & 115 & 109 & 1234 & 115 \\
\hline Kharistvala & 162 & 162 & 175 & 177 & 215 & 202 & 164 & 163 & 177 & 202 & 195 & 184 & 2178 & 160 \\
\hline Khvanchkara & 78 & 82 & 83 & 85 & 106 & 100 & 81 & 80 & 87 & 101 & 91 & 90 & 1067 & 90 \\
\hline
\end{tabular}

According to the table, the seasonal distribution of atmospheric precipitations over the whole territory of Racha is: there are two peaks of precipitation fall: maximum-in May $(105-215 \mathrm{~mm})$ and in October (99-202 mm), minimum-in August (79-163 mm) and in January (79-162 mm). On the territory of Racha, the most quantity of atmospheric precipitations is observed in Kharistvala $(2178 \mathrm{~mm}$ annually) that is mainly conditioned by its orographic conditions $[8,9]$.

The precipitation quantity during one rainfall is also significant. Flow formation and erosion development are highly influenced by precipitation intensity, i.e., the quantity ( $\mathrm{mm}$ ) of precipitation that falls in a unit of time. During heavy rains, when raindrops fall on the surface so rapidly that the soil cannot absorb it, a surface flow is formed, and it washes the soil off. The more persistent and longlasting the torrential rain is, the more dramatic is the effect of the erosive processes. During drizzling rains, soil washing-off is not observed, even in case of a high quantity of precipitations, or it is quite inconsiderable. 
The number of days with precipitations and their territorial distribution is especially significant for mountainous regions. During this period, the precipitation quantity was $\geq 30.0 \mathrm{~mm}$. This volume of precipitations is mostly observed in the warm period. The number of such days in Racha is 1-4 [10]. The number of days with $\geq 20.0 \mathrm{~mm}$ is also considerable (Table 4).

Table 4. The number of days with different quantities of precipitations

\begin{tabular}{|c|c|c|c|c|c|c|c|c|c|c|c|c|c|}
\hline \multirow[t]{2}{*}{ Object } & \multicolumn{5}{|c|}{ Month } & \multirow[b]{2}{*}{ VI } & \multirow[b]{2}{*}{ VII } & \multirow[b]{2}{*}{ VIII } & \multirow[b]{2}{*}{ IX } & \multirow[b]{2}{*}{$\mathrm{X}$} & \multirow[b]{2}{*}{$\mathrm{XI}$} & \multirow[b]{2}{*}{ XII } & \multirow[b]{2}{*}{$\begin{array}{l}\text { Per } \\
\text { year }\end{array}$} \\
\hline & I & II & III & IV & V & & & & & & & & \\
\hline AAmbrolauri & 14.2 & 13.5 & 14.0 & 13.0 & 14.8 & 12.7 & 10.8 & 9.7 & 10.1 & 11.5 & 10.9 & 12.8 & 148 \\
\hline Oni & 11.6 & 11.5 & 12.4 & 12.7 & 14.6 & 13.3 & 10.6 & 9.2 & 9.9 & 10.2 & 10.5 & 11.6 & 138 \\
\hline Shovi & 15.5 & 15.6 & 17.0 & 16.5 & 19.8 & 18.3 & 15.4 & 13.3 & 13.6 & 13.8 & 12.2 & 13.6 & 185 \\
\hline \multicolumn{14}{|c|}{$\geq 5.0 \mathrm{~mm}$} \\
\hline AAmbrolauri & 6.0 & 5.2 & 5.2 & 4.3 & 5.6 & 5.5 & 3.8 & 4.1 & 4.9 & 6.4 & 4.8 & 5.7 & 62 \\
\hline Oni & 4.7 & 4.6 & 5.1 & 5.4 & 6.4 & 6.0 & 4.9 & 4.4 & 4.9 & 5.5 & 5.3 & 5.3 & 62 \\
\hline Shovi & 5.3 & 5.9 & 5.4 & 6.2 & 7.4 & 7.6 & 6.2 & 6.3 & 6.3 & 6.0 & 4.4 & 4.3 & 71 \\
\hline \multicolumn{14}{|c|}{$\geq 20.0 \mathrm{~mm}$} \\
\hline AAmbrolauri & 0.8 & 1.0 & 0.4 & 0.5 & 0.7 & 1.0 & 0.8 & 0.9 & 1.2 & 1.5 & 1.1 & 1.0 & 11 \\
\hline Oni & 0.6 & 0.6 & 0.5 & 0.6 & 0.9 & 1.0 & 1.0 & 0.9 & 1.0 & 1.2 & 1.1 & 0.8 & 10 \\
\hline Shovi & 1.0 & 0.8 & 0.9 & 1.0 & 1.4 & 1.2 & 1.2 & 1.5 & 1.3 & 1.8 & 0.9 & 0.9 & 21 \\
\hline
\end{tabular}

The table shows that in the region of Racha, the number of days with $\geq 0.1 \mathrm{~mm}$ atmospheric precipitation is observed at $400-800 \mathrm{~m}$ above sea level and reaches its maximum in spring-13.0-14.8, totally 138-148 days annually. Below this height, the number of days with $\geq 5.0 \mathrm{~mm}$ precipitation is 4.3-6.4, a total of 62-71 days annually. Some days with $\geq 20.0 \mathrm{~mm}$ atmospheric precipitation reaches its maximum in summer and autumn- $1.0-1.5$, totally 10-11 days annually, while above $800-1600 \mathrm{~m}$ a.s.l. The number of days with precipitation grows, consecutive wet days (precipitation $\geq 0,1 \mathrm{~mm}$ ) totalling 16.5-19.8, the number of days with $\geq 5.0 \mathrm{~mm}$ atmospheric precipitation reaches its maximum in spring $6.7-7.4$ days and summer 5.4-7.6 days. The number of days with $\geq 20.0 \mathrm{~mm}$ atmospheric precipitation reaches its maximum in spring 1.0-1.4 days and summer 1.2-1.5 days, 21 days annually. Sometimes, recurrence of torrents and their intensity is $3-4 \mathrm{~mm} / \mathrm{min}$ with a duration of $2-3$ hours, maximum intensity- $1.9-6 \mathrm{~mm} / \mathrm{min}$.

Erosion development is also conditioned by solid precipitation such as snow. The thickness of the snow cover and the frozen soil cover, and the intensity of snow melting associated with it influenced the intensity of erosive processes. A thick snow cover protects the soil and its deep layers from freezing (when-20, $25^{\circ}$ and lower temperatures). Moreover, it contributes to its thawing by the warmth coming from the lower layers of the soil. During the snow melting process, an unfrozen soil more easily absorbs moisture and, in this way, decreases the surface flow. The snow cover thickness varies between 19 and $55 \mathrm{~cm}$ at $400-800 \mathrm{~m}$ above sea level. at $800-1600 \mathrm{~m}$, it is $69-79 \mathrm{~cm}$; at $1600-2000 \mathrm{~m}$ and higher, the snow cover thickness is $110-140 \mathrm{~cm}$. The speed of the snow melting process depends on the direction and exposition of a slope. Rapid melting is observed on southern, south-eastern and south-western slopes, as far as they are pretty warmed by the sun. The process is observed 5-10 days later on the southern slopes than on the southern ones. Therefore, erosion caused by thaw water is more frequent on southern slopes.

Air temperature influences liquid impact erosion mainly in spring, during the snow melting period. The rapid increase in temperature in this period causes a rise in the speed of the snow melting process that makes good conditions for the generation of the large flow of thaw water. The higher the air temperature, the more severe is the erosion (Table 5).

Table 5. Average air temperature in spring and average dates of snow melting

\begin{tabular}{|c|c|c|c|c|c|}
\hline \multirow[t]{2}{*}{ Object } & \multicolumn{3}{|c|}{ Month } & \multirow[t]{2}{*}{$\begin{array}{l}\text { Snowpack } \\
\text { breakdown }\end{array}$} & \multirow[t]{2}{*}{ Snow melting } \\
\hline & III & IV & $\mathrm{V}$ & & \\
\hline Ambrolauri & 5.5 & 11.3 & 15.8 & - & 21. III \\
\hline Oni & 4.2 & 9.8 & 14.4 & 2. III & 29. III \\
\hline Utsera & -1.2 & 3.8 & 9.6 & 11. IV & 23. IV \\
\hline Shovi & 5.6 & 11.2 & 16.3 & - & 18. III \\
\hline Kharistvala & -1.1 & 4.1 & 8.4 & 9. IV & 19. IV \\
\hline Khvanchkara & -0.2 & 5.5 & 11.7 & 7. IV & 18. IV \\
\hline
\end{tabular}


According to the table, at 400-800 m above sea level, the snow cover melts on 18-29 March (Chrebalo, Ambrolauri, Oni), at 800-1200 m-on 18 April and at 1200-1600 m-on 19-23 April (Ghebi, Shovi) [9].

Erosive processes are highly influenced by considerable variation in daily air temperature. In Racha, the average annual air temperature varies from $11.4^{\circ}$ to $-2.4^{\circ}$. The coldest month is January $\left(-0.2^{\circ},-12^{\circ}\right)$ and the hottest month is August $\left(23.8^{\circ}\right)$. In most of the territory (at 500-1600 m above sea level), the annual temperature amplitude is $22^{\circ}-23^{\circ}$, whereas, in the high-mountainous zone, it is $19^{\circ}$. In spring, low temperature at night causes soil freezing. During the daytime, the thin soil layer's surface thaws become saturated with water is easily washed off.

While studying erosive processes, it is essential to consider the structure of the soil cover and the water permeability of the soil, on which the value of the surface runoff depends and which is the primary reason for soil washing-off. Therefore, the water permeability of soil should be considered while undertaking anti-erosive activities and assessing a potential erosion hazard.

In the study region, when the daily quantity of the atmospheric precipitations is $100-120 \mathrm{~mm}$ and more during torrential rains, and there is a significant slanting of slopes, then liquid impact erosion occurs. In the zone of forest dark, grey and humus-carbonate soil, on the $10-15^{\circ}$ slopes, where hoeing cultures are grown, after one torrential rain $(0.5 \mathrm{~mm} / \mathrm{min}), 20-25 \mathrm{t} / \mathrm{ha}$ soil is washed off (Table 6).

Table 6. Washing soil off arable lands

\begin{tabular}{|c|c|c|c|c|c|c|}
\hline \multirow[t]{2}{*}{ Municipality } & \multirow{2}{*}{$\begin{array}{l}\text { Arable lands } \\
\text { completely } \\
\text { (Thousand ha) }\end{array}$} & \multirow{2}{*}{$\begin{array}{l}\text { Relief } \\
\text { inclination }\end{array}$} & \multirow{2}{*}{$\begin{array}{l}\text { Washing soil } \\
\text { off arable } \\
\text { lands in year } \\
\text { t/ha }\end{array}$} & \multicolumn{3}{|c|}{$\begin{array}{c}\text { Degree of soil erosion } \\
\text { Metric } \mathrm{t} / \mathrm{ha}\end{array}$} \\
\hline & & & & Low & Medium & High \\
\hline Ambrolauri & 2.7 & $15-20^{0}$ & $5-10$ & 1.0 & 0.8 & 0.3 \\
\hline Oni & 1.4 & $25^{0}>$ & $5-10 ; 20-25$ & 0.7 & 0.5 & 0.1 \\
\hline
\end{tabular}

On the territory of Racha, in Ambrolauri Municipality, from moderately slanting slopes (15-20 $)$, 5$10 \mathrm{t} / \mathrm{ha}$ soil is washed off annually, while in Oni Municipality, 20-25 t/ha soil is washed off on extremely slanting (over $25^{\circ}$ ) slopes [11].

Erosion is in close relation to vegetation cover. Vegetation cover continuously decreases the development of erosion or completely stops it. Vegetation cover is also essential for improving the soil structure. It raises water permeability, i.e., contributes to anti-erosive stability. We may distinguish three main categories of plants regarding soil-conserving: forest plants, natural-grassy plants, and cultural plants [12].

The soil-conserving value of forest vegetation is determined by a crown and form of timber trees, plant age, undergrowth and grass cover and blanket, and their use in economics.

The most quantity of soil is washed off at bare places and the least-in the forests of 0.5-0.6 density. In spring, during heavy rains $(1.37 \mathrm{~mm} / \mathrm{min})$, oak-oriental hornbeam forest of density 0.8 decreases surface liquid flow 17 -folds, pine forest -8 times, fir-deciduous forest-9 times and closed grass cover1.8-2.9 times, e. i., during the period of intensive snow melting process the role of grass cover as of a liquid regulator is significantly decreased compared to the forest [13].

Anthropogenic economic activities often harm the soil-conserving function of the forest. Forest clearance causes soil degradation, especially in forests where density is less than 0.5 as far as forest blanket and undergrowth is cleared. In the regions of Racha, where forests are chopped down, and cattle graze at forest edges and in sparse forests, the water permeability of forest soil becomes considerably low, and the surface liquid flow increases 10-15 times.

The soil-conserving value of natural grassy plants is determined by its florist composition, perspective coverage ratio, turning into the meadow, the system of roots in the meadow, saturation of the soil with roots. Resistance of soil against washing-off depends on morphologic properties of plants, namely, on the root system.

The most effective soil-conserving properties are observed in the communities, where grains and many grasses with root runners and roots dominate in the meadow composition. Annual plants are characterized by the worst soil-conserving properties. Soil-conserving properties are not entirely characteristic of bush-grass, mat-grass, common bentgrass. At the same time, we should note that the species mentioned above, except bush-grass, are resistant to grazing, through meadows of mixed grasses 
of bush-grass and bentgrass-bushgrass are most frequently mowed contributes to the development of erosive processes.

The principal role regarding soil-conserving is assigned to above-ground parts of plants and projective plant cover of the surface. For example, a decrease in projective cover by $70-80 \%$ increases surface flows, though the soil is not almost washed off. A decrease in projective cover by $50 \%$ increases the surface flow, and washing-off also occurs. A decrease in projective cover by $30-40 \%$ makes washing-off significant. After a decrease by less than $30 \%$ in projective cover, the surface flow and washing-off are incredibly high, and many gullies and narrow valleys are formed. The higher the grassy cover and the more the number of layers, the more the soil is protected from the mechanical influence of rain.

In the local development of erosion, the significance is the mosaic layout of the plant community. The larger the mosaic, the greater the risk of erosion.

The intensity of soil washing-off also depends on different agricultural species. The most soilconserving properties against erosion are characteristic of perennial grass species (I soil-conserving category), annual grassy species and autumn (II soil-conserving category), and spring (III soilconserving category), cereal crops are characterized with less soil-protecting properties while hoeing species have the least soil-conserving properties.

Thus, the soil-protecting roles of different cultures vary and depend on the projective cover of the land surface and the state of the root system. The analyses of literary data [13-15] and field investigation enable us to distinguish the four soil-conserving categories of forest vegetation (Table 7).

Table 7. Soil protection categories of forest vegetation

\begin{tabular}{|c|c|c|c|}
\hline $\begin{array}{l}\text { Category of } \\
\text { forest vegetation }\end{array}$ & $\begin{array}{l}\text { Frequency of } \\
\text { forest plantations }\end{array}$ & Main woody species & Condition of forest \\
\hline High resistance to erosion & $0.9-0.8$ & $\begin{array}{l}\text { Oak and oriental } \\
\text { Hornbeam forest, } \\
\text { Hornbeam forest. }\end{array}$ & $\begin{array}{l}\text { Projection coverage } \\
\text { between trees } 90 \%-80 \% \text {; }\end{array}$ \\
\hline $\begin{array}{l}\text { Medium resistance to } \\
\text { erosion }\end{array}$ & $0,7-0.6$ & $\begin{array}{l}\text { Spruce and deciduous } \\
\text { Forest (chestnut, beech, } \\
\text { lime, ash, maple). }\end{array}$ & $\begin{array}{l}\text { Projection coverage } \\
\text { between trees } 70 \%-60 \% \text {; } \\
\text { Sparse undergrowht, grassy } \\
\text { cover is not common, } \\
\text { forest floor is intact. }\end{array}$ \\
\hline Low resistance to erosion & Less than 0.5 & $\begin{array}{l}\text { Pine forests; } \\
\text { bilberry, sea buckthorn, } \\
\text { juniper and etc. }\end{array}$ & $\begin{array}{l}\text { Projection coverage } \\
\text { between trees } 50 \%-40 \% \\
\text { Weakly developed undergrowth; } \\
\text { forest floor is } \\
\text { undeveloped or degraded. }\end{array}$ \\
\hline $\begin{array}{l}\text { Very low resistance to } \\
\text { erosion }\end{array}$ & Less than 0,3 & $\begin{array}{l}\text { Pontic rhododendron, } \\
\text { cherry laurel, bladder-nut, } \\
\text { hawthorn, dogwood, } \\
\text { medlar, bilberry and etc.; } \\
\text { Grassy plants: bushgrass, } \\
\text { mat-grass, common bentgras. }\end{array}$ & $\begin{array}{l}\text { Projection coverage } \\
\text { etween trees is less than } 30 \% \text {, } \\
\text { he herbaceous layer is not } \\
\text { developed or only weakly } \\
\text { developed; the undergrowth is sparse } \\
\text { to absent; the forest floor is severely } \\
\text { degraded. }\end{array}$ \\
\hline
\end{tabular}

Erosive processes, especially lateral erosion, are one reason for landslide formation. The main factor that causes generation and activation of landslide processes are complex geologic structure, distribution of rocks with low physical properties on large areas, deep fragmentation of relief and excess of extremely slanted surfaces, a large number of tectonic clefts, high seismic activity, variation of climate conditions and contrasting meteorological elements. Activation of landslide processes highly depends also on anthropogenic economic activities.

The areas of some landslides reach hundreds of hectares. For example, in Oni Municipality, the area of the Somitso Landslide is 550 ha, the Zhashkva Landslide area is 1500 ha, the volumes of which vary from several thousand $\mathrm{m} 3$ to tens and hundreds of millions of cubic meters. The volume of the Chorda Landslide is $150 \mathrm{mln} \mathrm{m} 3$, and the Zhashkva Landslide volume is $200 \mathrm{mln} \mathrm{m} 3$ (in Oni Municipality), etc. The most active landslides are observed in Parakheti, Shardometi, Tsedisi and Ghebi. The 1991 Racha Earthquake with magnitude 7.2 and intensity IX, which along with the 1988 Spitak Earthquake (Armenia), is the strongest among the earthquakes recorded in the Caucasus so far, in village Chorda triggered a massive landslide (volume $150 \mathrm{mln} \mathrm{m} 3$ ) that destroyed the village of 70 households. 
Landslides with volumes of 170-200 mln m3 were formed on the territories of Zhashkva and Bajikhevi [16].

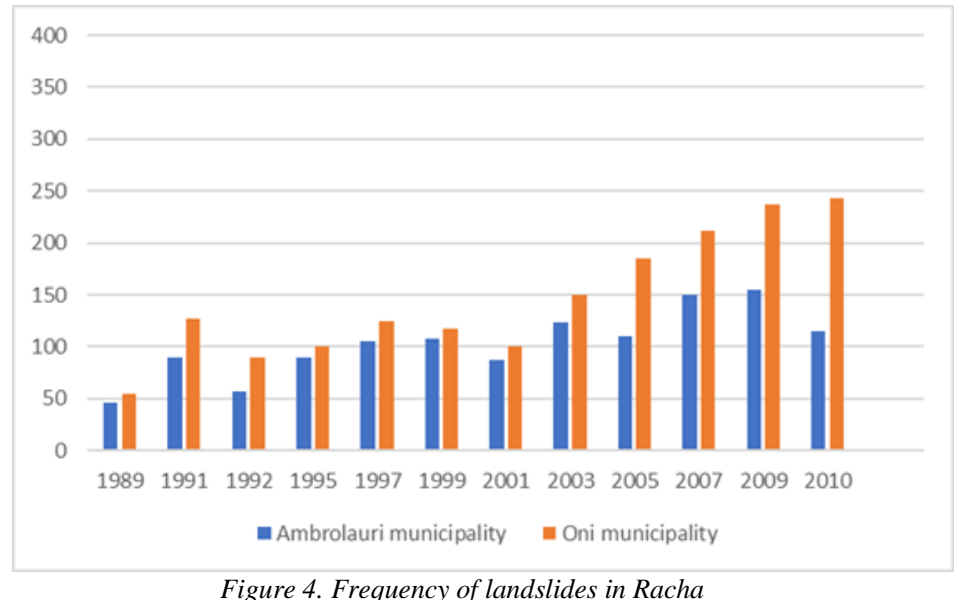

The upper Cretaceous Eocene sandy-clayey and lower Cretaceous and Jurassic clayey facies rocks are prone to a significant risk of high-intensity development of landslide processes.

According to the landslide damage and hazard risk zoning of the territory of Georgia, Racha belongs to extremely high (0.9-0.7) and high (0.7-0.5) risk categories [16].

The landslide dynamics directly relate to the quantitative value of seasonal and annual atmospheric precipitations. Landslide activation periods immediately coincide with the positive balance of atmospheric precipitations regarding average long-term value.

Based on the studies of the properties of geomorphologic and composing rocks, there are certain regularities in the formation of mudflow foci. Foci transformed by erosion and erosion-landslide processes dominate in the foothills and low mountain zones; gravitational-landslide processes are observed in the middle mountain zone; in high mountain zones, gravitational processes are formed because of solifluction and snow avalanches. Mudflows are formed in the alpine-nival belt, and socalled "glacial mudflows" are observed in Quaternary glaciation sediments and moraine sediments of the modern glaciers [6]. The quantity of mudflows is increased because of exceeding the average longterm precipitation norm and anthropogenic load, especially forest clearance.

According to the risk of damage caused by mudflow processes on the territory of Georgia, the region of Racha includes an extremely "great hazard" (0.8-0.6) area, which covers the middle mountain and high mountain belts of Racha, the zones of Jurassic slates and terrigene-carbonate flysch. It mainly covers the territory of Oni Municipality. The "considerable" mudflow area covers the middle mountain and low mountain belts in Ambrolauri Municipality and the low mountain belt in Oni Municipality. The area of "weak" (less than 0.01) mudflows covers the foothill zone, the part of the Racha Ridge built of carbonate rocks. Mudflows are most characteristic of the rivers originating from the Shoda-Kedela Ridge (the head river Rioni): Sakhrikilo, Gizhura, Shodura, Lagora, Sakaura. In summer 2020, as a result of the flood and mudflow caused by overflowing of the rivers Sakaura (the right tributary of the river Rioni) and Rioni, the Tbilisi-Oni main highway was substantially damaged, a bridge collapsed, village Lagvanta and several other villages were left entirely isolated from the regional centre and were enormously damaged.

Mudflows are also common in the basins of the rivers Kondarula, Tchioriskhevi, Shkhiroruli, Dagoruli, Rubodzali, Sasvanostskali, Barula, Shardometiskhvi, Tcheshora, Seva and Parakheti.

\section{Conclusion}

The analysis of the physical-geographical and anthropogenic factors of Racha, which was conducted in order to reveal their influence on geodynamical processes, enables us to make the following conclusions: more than half (59.1\%) of the total area of Racha, which is mountainous and fragmented into deep gorges, includes the height belt of $1500 \mathrm{~m}$ and higher than $3500 \mathrm{~m}$ above sea level. Among them, the middle mountain belt covers $33.8 \%$, and the high mountain belt occupies $25.3 \%$ of the territory, where the relief surfaces are significantly slanted, making suitable conditions for developing geodynamical processes. Arable lands are on the plateaus of river gorges and different declination 
slopes of mountains. Among them moderately declined $\left(15-20^{\circ}, 20-25^{\circ}\right)$ reliefs cover $30.4 \%$ of the territory, remarkably declined-19.2\% and sheer cliff relief- $2.8 \%$.

The mountainous, extremely fragmented relief, the climatic conditions, often unreasonable economic activities (clearance of soil-conserving forests, wrong land farming activities on mountain slopes, washing-off of pastures) contributes to the rapid development of liquid impact erosion that later causes washing-off processes in the upper layers of arable lands. In the Racha region, among 4.1 thousand ha of arable lands, the value of the soil washed off extremely slanted (over $25^{\circ}$ ) slopes is $20-25 \mathrm{t} / \mathrm{ha}$ annually.

Regarding the development of geodynamical processes, the most significant is heavy and intensive precipitations because of climatic conditions, when precipitation quantity is $\geq 20.0 \mathrm{~mm} \geq 32.0 \mathrm{~mm}$ and, correspondingly, their number is 21 and 5 days a year.

As to the lithological composition, significantly slanted slopes built up of lower and upper Cretaceous Neocomian Eocene limestone, marl, sandstone, terrigenous flysch, argillaceous shale and sandstone are less resistant to erosive, landslide and mudflow processes.

The vegetation cover plays a significant role regarding soil-conserving, especially the forests of timber trees. Racha is abundant in forests. Among them, high soil-conserving ability is characteristic of the forest vegetation, where projective cover between forests is $90-80 \%$, and forest density is $0.9-0.8$. These are oak-oriental hornbeam and oak-hornbeam forests, which can be assigned to the category of forest non-prone to erosion. However, when projective cover is less than $30 \%$, and the density of forest vegetation is less than 0.4 , the grass cover is badly developed, the undergrowth is sparse, or it does not exist at all, such type of forests should be considered as ones prone to erosion hazard.

\section{Competing interests}

The authors declare that they have no competing interests.

\section{References}

[1] Salukvadze, E., Chaladze, T., Gogidze, K. (2021). The Natural Resources Potential and Exploitation Peculiarities of Mountainous Regions (on the example of Lower Racha). Georgian Geographical Journal, 1(1), 42-53. https://doi.org/10.52340/ggj.2021.258

[2] Saneblidze, M., Ukleba, D., Khazaradze, R. (2000). Christephore Jakeli (1970) Sakartvelos Landshapturi ruk'a. [Landscape Map of Georgia (1: 600 000)], Tbilisi-Moscow: Main Department of Geodesy and Cartography/Russia, Moscow: (in Georgian).

[3] Ukleba, D., Budagov, B., Useibov, M., Sokhadze, E., Bagdasarov, A. (1983). Landšaftnaja karta Zakavkazija, Glavnyi departament geodezii i kartografii - [Landscape map of the South Caucasus, (1: 600 000)], Main Department of Geodesy and Cartography/ Russia, Moscow: (in Russian).

[4] Map Topographic Racha region (1: 50 000, 1: 100 00) designed in 1950-63 and updated in 1976 by the Russian Military Headquarters, Moscow, 1976 (in Russian).

[5] Gobejishvili, R. (2000). Rach'a-Lechkhumi//In: Sakartvelos geograpia, nats’ili I, Pizik'uri geograpia - RachaLechkhumi//In: Geography of Georgia, Part I, [Physical Geography of Georgia], Tbilisi: Metsniereba, 256-258 p.; (in Georgian)

[6] Tsereteli, E., Tsereteli, Dj. (1985). Osobennosti razvitija selevix processov v Gruzii//In: Geologičeskie uslovija razvitia celey v Gruzii.[Features of the development of mudflow processes on the territory of Georgia],In: geological conditions for the development of mudflows in Georgia//Georgia, Tbilisi: Mecniereba, 9-15 p.; (in Russian).

[7] Goishvili, B. (2012). Rach 'is geoekologia, geologia, stikiuri movlenebi da geokimiuri prots'esebi//In: Rach'a: ts'arsuli, ats'mq'o, momavali/Sakartvelos mets'nierebata ak'ademiis mtis problemebis k'ompleksuri shests'avlis k'omisia. [Geoecology of Racha, Geology, Hazards processes and geoshemical phenomena], in Racha Past, Present, Future. Georgia, Tbilisi, p. 94-96; (in Georgian)

[8] Sakartvelos samets 'niero da gamoq'enebiti klimaturi ts'nobari. [Scientific and applied reference book of climate in Georgia], (2004), Part I., Tbilisi: Bakur Sulakauri Publishing, p. 55-82; (in Georgian)

[9] Meladze, G., Meladze, M. (2012). Rach'a-Lechkhumi-Kvemo Svaneti//In: Sakartvelos dasavlet regionebis agroklimaturi resursebi//Racha-Lechkhumi-Kvemo Svaneti [In: Agroclimatic resources of Western regions of Georgia], Tbilisi: Universali, p. 404-406 (in Georgian) 
[10] Javakhishvili, Sh. (1977). Atmosperuli nalek'ebi//nn: Sakartvelos klimatograpia [Atmospheric precipitation], In: Climatography of Georgia. Georgia,Tbilisi: Tbilisi University Publishing House, p. $69-76$ (in Georgian)

[11] Gogichaishvili, G. (2012). Niadagis ch'amoretkhiloba sakhnavi mits'ebidan, In: Sakartvelos erovnuli atlasi [In: washing soil off arable lands] In:. National atlas of Georgia, p. 74; (in Georgian)

[12] Machavariani, V. (1987). Erozia počv//In: Generalnaja cxema protivoerozionnix meropriatyi Gruzinskoy SSR na 1981-1990 godi i na period do 2000 goda. [Soil erosion], in: General scheme of anti-erosion measures of the Georgian SSR for 1981-1990 and for the period up to 2000/Georgia, Tbilisi, p. 132-136; (in Russian)

[13] Kharaishvili, G. (1988). Mtis tq'eebis ts'kaldats'viti da niadagdats'viti roli//In: Tq'is roli bunebis dacvis sakmeshi [Water protection and soil protection role of mountain forests], in: The role of forests in nature protection/ Georgia,Tbilisi:Tsodna, p.14 -18 (in Georgian)

[14]Zharkova, Y. (1976). Ocenka potencialnoy opasnosti erozii v svjazi rastitelnim pokrovom//In: Ocenka I kartografirovanie erozionnoopasnix deflacionnix zemel.[ Assessment of potential erosion hazards with regard to vegetation cover changes]. In: Land erosion and deflation assessment and mapping. Russia, Moscow: Moscow University Publishing House, p. 94-96; (in Russian)

[15] Kandelaki, T. (2012). Rach' is regionis tq'is resursebi//In: Rach'a: ts'arsuli, ats'mq'o, momavali/Sakartvelos mets'nierebata ak'ademiis mtis problemebis k'ompleksuri shests'avlis k'omisia. [Forest resources of the Racha region], in: Racha Past, Present, Future. Georgia, Tbilisi, p. 286-290 (in Georgian)

[16] Tatashidze, Z., Tsereteli, E., Khazaradze, R. (2000). Stikiuri bunebrivi movlenebi//In: In: Sakartvelos geograpia, nats'ili I, Pizik'uri geograpia [Elemental narulal processes], In: Geography of Georgia, Part I, [Physical Geography of Georgia], Tbilisi: Metsniereba, 69-83p.; (in Georgian). 